\title{
Resting Behavior of Malaria Vectors in Ghana and Its Implication on Vector Control.
}

\author{
Akua Obeng Forson \\ Department of Medical laboratory Sciences: University of Ghana \\ Isaac A. Hinne \\ University of Ghana Medical School: University of Ghana School of Medicine and Dentistry \\ Shittu B. Dhikrullahi \\ University of Ghana Medical School: University of Ghana School of Medicine and Dentistry \\ Isaac Kwame Sraku \\ University of Ghana Medical School: University of Ghana School of Medicine and Dentistry \\ Abdul Rahim Mohammed \\ University of Ghana Medical School: University of Ghana School of Medicine and Dentistry \\ Simon K. Attah \\ University of Ghana Medical School: University of Ghana School of Medicine and Dentistry \\ Yaw A Afrane ( $\square$ yaw_afrane@yahoo.com) \\ Department of Medical Microbiology, College of Health Sciences, University of Ghana
}

\section{Research}

Keywords: Ghana, Anopheles coluzzii, Anopheles gambiae complex., resting behavior, insecticide resistance, human blood index, sporozoite rates.

Posted Date: January 3rd, 2022

DOI: https://doi.org/10.21203/rs.3.rs-1200487/v1

License: (c) (i) This work is licensed under a Creative Commons Attribution 4.0 International License. Read Full License 


\section{Abstract}

Background: In Sub-Saharan Africa, there is widespread use of long-lasting insecticidal nets (LLINs) and Indoor residual spraying (IRS) to help control the density of malaria vectors and decrease the incidence of malaria in communities. An understanding of the interactions between increased insecticide use and resting behaviour patterns of malaria mosquitoes is important for an effective vector control programme. This study was carried out to investigate the resting behavior, host preference and infection with Plasmodium falciparum of malaria vectors in Ghana in the context of increasing insecticide resistance in malaria vectors in sub-saharan Africa.

Methods: Indoor and outdoor resting Anopheline mosquitoes were sampled during the dry and rainy seasons in five sites that were in 3 ecological landscapes [Sahel savannah (Kpalsogou, Pagaza, Libga), Coastal savannah (Anyakpor) and Forest (Konongo) zones] using pyrethrum spray catches (PSC), mechanical aspiration (Prokopack) for indoor collections, pit shelter and Prokopack for outdoor collections. PCR based molecular diagnostics were used to determine mosquito speciation, genotype for knockdown resistance mutations (L1014S and L1014F), G119S Ace-1 mutation, specific host blood meal origins and sporozoite infection in field collected mosquitoes.

Results: Anopheles gambiaes. I. was the predominant species (89.95\%, $\mathrm{n}=1,718)$, followed by An. rufipes (8.48\%, $\mathrm{n}=162)$, and An. funestus s. I. (1.57\%, $\mathrm{n}$ = 30). Sibling species of the Anopheles gambiae revealed An. coluzzii accounted for $63 \%$ (95\% Cl: 57.10 - 68.91), followed by An. gambiae s. s [27\% (95\% Cl: 21.66 - 32.55)], and An. arabiensis [9\% (95\% Cl: 6.22 - 13.57)]. The mean resting density of An. gambiae s. I. was higher outdoors (79.63\%; $1,368 / 1,718)$ than indoors $(20.37 \% ; 350 / 1,718)(z=-4.815, p<0.0001)$. The $k d r$ west L1014F and the Ace-1 mutations were highest in indoor resting An. coluzzii and An. gambiae in the sahel-savannah sites compared to the forest and coastal savannah sites. Overall, the blood meal analyses revealed a large proportion of the malaria vectors preferred feeding on humans $(70.2 \%)$ than animals $(29.8 \%)$ in all sites. The sporozoite rates was only detected in indoor resting An. coluzzii from the sahel savannah (5.0\%) and forest (2.5\%) zones.

Conclusion: The study reports high outdoor resting densities of An. gambiae and An. coluzzii with high $k d r$ west mutation frequencies, and persistence of malaria transmission indoors despite the use of LLINs and IRS. Continuous monitoring of changes in resting behavior of mosquitoes and implementation of complementary malaria control interventions are needed to target outdoor resting Anopheles mosquitoes in Ghana.

\section{Introduction}

Malaria is a major public health problem in Africa and was responsible for an estimated 229 million episodes and 409000 deaths in 2019 . In Ghana, malaria is responsible for more than 5.5 million infections and 37 deaths for every 1,000 population $(1,2)$ despite tremendous efforts in the scale-up of vector control interventions particularly in the use of long-lasting insecticidal nets (LLINs) and indoor residual spraying (IRS) $(3,4)$. These anti-vector control interventions previously led to a remarkable reduction of vector population (5-8) and malaria transmission $(9,10)$. However, there are reports of resurgence of malaria in many parts of sub-Saharan Africa $(11,12)$. Some of the challenges implicated in the resurgence is the emergence of insecticide resistance, behavioral modification (shift in the biting and resting behavior from indoor to outdoor) and changes in host species preferences from humans to animals $(6,13-15)$.

These challenges have arisen as an adaptation by the malaria vectors response to high use of insecticides for vector control. For instance, following the introduction of LLIN there has been reports of shift in biting behavior of Anopheles gambiae and An. funestus in Kenya $(6,16)$ and An. funestus in Benin and Senegal $(17,18)$. Whilst the long-term use of LLIN has increased the outdoor feeding proportion of An. gambiae and An. melas in Equatorial Guinea (13), in Tanzania, the long-term use of LLINs was reported to be associated with shifts in the outdoor resting rate of An. gambiae, An. arabiensis and An. funestus $(14,19)$. These behavioral changes however are not consistent with some countries reporting high indoor resting densities of An. gambiae and An. funestus despite long-term use of LLIN and IRS (20-22). Furthermore, the widespread insecticide resistance in malaria vector populations in Africa is a major threat to current malaria control programmes. Studies from Côte d'Ivoire (23), Togo (24, 25), Benin (26), Burkina Faso (27, 28), Cameroon (29, 30), and Kenya $(31,32)$ have reported high metabolic resistance and target site modification of insecticides in the malaria vector. In Ghana, the common target site resistance mechanisms in malaria vectors are the Ace-1 mutation in acetylcholine esterase gene G119S that causes resistance to organophosphates and carbamates, and the voltage-gated sodium channel knockdown resistance ( $K d r)$ which play a major role in resistance to pyrethroids are the most important mechanisms (33-35).

The primary malaria vectors in Ghana are the Anopheles gambiae sensu lato (An. gambiaes. s., An. arabiensis, An. coluzzii and An. melas) and Anopheles funestus. However, in view of the increasing concern about resurgence of malaria transmission in Africa $(36,37)$, there is a need to enhance control intervention strategies by having a better understanding of vectors resting and feeding behavior in their different specific settings and varying seasonal patterns. This is very crucial for the success of the current vector control tools and will provide a guide to improve efforts for the control of malaria in endemic regions.

The objective of this study was to investigate the resting behavior, species composition, insecticide resistance status, and Plasmodium falciparum infections of malaria vectors in three ecological settings of Ghana (the coastal savannah in the south, the forest in the middle, and the Sahel savannah in the north). These ecological zones have varying suitable weather and environmental conditions to sustain the propagation of Anopheles mosquitoes and malaria parasites (38). The coastal savannah and forest zone have a bimodal rainfall pattern, allowing for two peaks of malaria transmission while the Sahel zone has a unimodal rainfall pattern making malaria transmission seasonal. Information from this study could provide a better understanding of the impact of current malaria control programme effects on malaria vector population and their interaction on resting behavior. 


\section{Materials And Methods \\ Study sites}

This study was carried out in five sites in three ecological landscapes of Ghana; Anyakpor in the coastal savannah zone, Dwease in the forest zone, and Kpalsogou, Libga and Pagaza in the Sahel savannah zone (Figure 1).

Anyakpor ( $5^{\circ} 46^{\prime} 51.96$ " $\mathrm{N} \mathrm{0} 35^{\prime} 12.84$ "E) is a village in the coastal savannah zone, about $5 \mathrm{~km}$ west of Ada Foah in Southern Ghana. The coastal savannah has a tropical savannah climate, with an average annual precipitation of $787 \mathrm{~mm}$. Dwease $\left(6^{\circ} 32^{\prime} 3.05^{\prime \prime} \mathrm{N} 1^{\circ} 14^{\prime} 42.22\right.$ "W) a village near Konongo, in the Asante-Akim Central district in the middle of Ghana was the site located in the forest zone. The forest zone has a tropical rainforest climate, with an average annual precipitation of $1399.5 \mathrm{~mm}$. The climate in both the coastal savannah and forest area generally consists of a bimodal pattern of rainfall, with the long rainy season from March to June, and the short rainy season from October to November with mean annual temperature of $26.5^{\circ} \mathrm{C}$

Sites in the Sahel savannah ecological zone consisted of Kpalsogou ( $9^{\circ} 33^{\prime} 45.2$ "N $1^{\circ} 01^{\prime} 54.6$ "W), a village in the Kumbungu district of the northern region, Pagaza $\left(9^{\circ} 22^{\prime} 33.34\right.$ "N $\left.0^{\circ} 42^{\prime} 29.67 \mathrm{~W}\right)$ in the Tamale metropolitan area and Libga $\left(9^{\circ} 35^{\prime} 32.26\right.$ "N $0^{\circ} 50^{\prime} 48.8$ "W), a village in the Savelugu-Nanton District. They have a unimodal rainfall pattern from May to November with a mean annual temperature of $28^{\circ} \mathrm{C}$, which can get to a maximum of $42^{\circ} \mathrm{C}$

\section{Study Design}

Mosquitoes were sampled during the rainy season in May for the sites in the coastal and forest zones (Anyakpor and Konongo respectively) and September for the sites in the Sahel savannah zones (Pagaza, Libga, and Kpalsogou) and the dry season in February to March at all the study sites in 2019. Sixteen houses were randomly selected in each study site and during each sampling night four houses were sampled for mosquitoes. Sampling was done over 4 days each during the dry and rainy seasons. The GPS coordinates of each site was determined and recorded.

Malaria vectors resting indoors were sampled using pyrethrum spray catches (PSCs) from 05.00 - $07.00 \mathrm{~h}$ (39). The Prokopack aspirator (John W Hock, Gainesville, FL, USA) was used to collect mosquitoes resting indoors and outdoors from $05.00-07.00 \mathrm{~h}$ (40). For indoor collections, mosquitoes resting on the walls and under the roofs of houses or ceilings, under beds were systematically aspirated. Outdoor sampling points included kitchens, granaries, animal resting places and evening outdoor human resting points. Additionally, outdoor resting mosquitoes were collected from pit shelters constructed according to Muirhead-Thomson's method (41) within 20 m of each selected house. Resting mosquitoes in the cavities created in the pit shelter were collected from 06:00 to 07:00 $\mathrm{h}$ by using hand-held mouth aspirators.

\section{Morphological Identification}

All caught mosquitoes were counted and Anopheline mosquitoes were sorted morphologically according to the identification keys of Gillies and Coetzee (42). Sampled mosquitoes were further classified according to abdominal status as unfed, freshly fed, half-gravid and gravid. Mosquitoes from each collection method were stored in separately labeled vials with 95\% ethanol. Samples were stored at the insectary of the Department of Medical Microbiology, University of Ghana Medical School, Accra, Ghana, until required for further processing.

\section{Sibling Species Discrimination}

Sibling species of the An. gambiaes. I. complexes were distinguished using the protocols of Scott et al. (43) and Fanello et al. (44). One leg from each mosquito serving as a DNA template was placed directly into the PCR master mix for Amplification.

\section{Detection Of Sporozoites}

The head and thorax of individual mosquito samples collected were used to detect the presence of $P$. falciparum sporozoites using sporozoite Polymerase Chain Reaction (PCR) as described by Echeverry et al. (45).

\section{Detection Of Blood Meal Sources}

The abdominal sections of blood-fed Anopheles mosquitoes were cut transversely between the thorax and the abdomen. Genomic DNA was extracted from mosquito abdomens using the ZR DNA MicroPrep ${ }^{\text {TM }}$ kit (Zymo Research, CA) following the manufacturer's instructions. One universal reverse primer and five animal-specific forward primers (human, cow, goat, pig, and dog) were used for amplification of cytochrome $b$ gene encoded in the mitochondrial genome to test for specific host blood meal origins using conventional PCR (46). Positive controls were included for each host during the PCR analyses and laboratory reared unfed An. gambiae was used as negative control.

Genotyping for kdr and Ace-1 mutations 
To genotype for $k d r$ mutations, DNA was extracted from mosquito legs using the ZR DNA MicroPrep ${ }^{\text {TM }}$ kit (Zymo Research, CA) following the manufacturer's instructions. Standard PCR assays for L1014F kdrallele was used to test the presence of the kdr gene using a modification of the protocol by Ahadji-Dabla et al. (2019). In addition, the G119S mutation on the Ace-1 gene was assessed using the PCR protocol described by Weill et al. [23].

\section{Data Analysis}

Resting densities of Anopheline mosquitoes was calculated as the number of female mosquitoes per trap/night for each trapping method. The MannWhitney $\mathrm{U}$ test was used to compare malaria vector density between indoor and outdoor locations. Chi-square was used to test the difference in seasonal abundance and malaria vector species composition between resting locations (indoor and outdoor).

Human blood index $(\mathrm{HBI})$ was calculated as the proportion of blood-fed mosquito samples that had fed on humans to the total tested for blood meal origins. The sporozoite infection rate (IR) expressed as the proportion of mosquitoes positive for Plasmodium sporozoite was calculated by dividing the number of sporozoite positive mosquitoes by the total number of mosquitoes assayed.

The KdrL1014F and Ace-1 G119S mutation frequencies was calculated according to the following formula (47):

$$
\mathrm{F}=\frac{2 \text { (HomozygoteResistant })+ \text { HeterozygoteResistant }}{2 \text { (totalnumberofspecimenanalyzed) }}
$$

Sporozoite rates was calculated for examining pooled samples of mosquitoes using the Gu W. D. (48) formula below:

$$
\backslash \text { varvec } S=\frac{\text { No. ofpositivepools }}{\text { No. ofpools } \times \text { Maximumpoolsize }} \times 100 \backslash \%
$$

\section{Results}

\section{Indoor and Outdoor resting densities of female Anopheles mosquitoes}

A total of 4,810 mosquitoes belonging to four genera were collected during the sampling period. Of these, 1,910 (39.71\%) were Anopheles mosquitoes, 2,814 (58.50\%) were Culex, 82 (1.70\%) were Aedes, and 4 (0.08\%) were Mansonia. The 1,910 Anopheles mosquitoes comprised of 1,718 (89.95\%) An. gambiaes. I, 162 (8.48\%) An. rufipees, and 30 (1.57\%) An. funestus. Overall, 81.57\% (1,558/1,910) of the Anopheles mosquitoes caught at the different sites were resting outdoors and $18.43 \%(352 / 1,910)$ were resting indoors ( $z=-4.970, p<0.0001)$. The mean resting density of An. gambiae s. I. was higher outdoors $(79.63 \% ; 1,368 / 1,718)$ than indoors $(20.37 \% ; 350 / 1,718)(z=-4.815, p<0.0001)$. More An. funestus were resting outdoors $93.33 \%$; $28 / 30)$ compared to indoors $(6.67 \% ; 2 / 30)(z=-2.039, p<0.0001)$. In addition, all $(100 \%)$ of the An. rufipes caught in this study were resting outdoors.

In Kpalsogou, Pagaza and Libga (Sahel savannah zone), a total of 1,372, 104 and 76 female Anopheline mosquitoes were caught, whilst in Anyakpor (coastal savannah zone) and Konongo (forest zone) a total of 52 and 114 respectively were caught (Table 1). Out of the 1,372 An. gambiae s. I. collected in Kpalsogou, $13.41 \%$ [184/1372 (95\% Cl: 11.68 - 16.24)] were resting indoors and 86.59\% [1,188/1,372(95\% Cl:84.64 - 88.32)] were resting outdoors (Table 1). All the An. funestus [100\% (22/22)] and An. rufipes [100\% (158/158)] were caught resting outdoors in Kpalsogou. In Pagaza and Libga, 7.7\% [8/104 (95\% Cl: 3.62- 15.04)] and 50.0\% [38/76 (95\% Cl: 39.03 - 60.10)] of An. gambiae were resting indoors, and 92.3\% [96/104 (95\% Cl: 84.96- 96.38)] and 50.0\% [38/76 (95\% Cl: $39.03-60.10)$ ] were caught resting outdoors. More Anopheles gambiae s. I. were caught resting indoors in Anyakpor [84.6\% (44/52) (95\% Cl: 71.37 - 92.66)] and Konongo [66.7\% (76/114) (95\% Cl: $57.14-75.05]$, than outdoors [15.4\% (8/52) (95\% Cl: 7.34 - 28.63)] and 33.3\% [38/114 (95\% Cl: $24.95-42.86)]$ respectively. 
Table 1

Resting densities of mosquitoes collected from different sites in the three ecological zones in Ghana.

\begin{tabular}{|c|c|c|c|c|c|}
\hline Site & Mosquito Species & Indoor No. (\%) & Outdoor No. (\%) & & Total No. \\
\hline \multirow[t]{3}{*}{ Kpalsogou } & An. gambiaes. I. & $184(13.41)$ & 1188 (86.59) & 1372 & \\
\hline & An. funestus s. I. & 0 & $22(100)$ & 22 & \\
\hline & An. rufipes & 0 & $158(100)$ & 158 & \\
\hline \multirow[t]{3}{*}{ Pagaza } & An. gambiaes. I. & 8 (7.69) & $96(92.31)$ & 104 & \\
\hline & An. funestus s. I. & 0 & 0 & 0 & \\
\hline & An. rufipes & 0 & 0 & 0 & \\
\hline \multirow[t]{3}{*}{ Libga } & An. gambiaes. I. & $38(50)$ & $38(50)$ & 76 & \\
\hline & An. funestus s. I. & $2(50)$ & $2(50)$ & 4 & \\
\hline & An. rufipes & 0 & 0 & 0 & \\
\hline \multirow[t]{3}{*}{ Anyakpor } & An. gambiaes. I. & 44 (84.62) & $8(15.38)$ & 52 & \\
\hline & An. funestuss. I. & 0 & 0 & 0 & \\
\hline & An. rufipes & 0 & $4(100)$ & 4 & \\
\hline \multirow[t]{3}{*}{ Konongo } & An. gambiaes. I. & 76 (66.67) & 38 (33.33) & 114 & \\
\hline & An. funestus s. I. & 0 & $4(100)$ & 4 & \\
\hline & An. rufipes & 0 & 0 & 0 & \\
\hline \multirow[t]{3}{*}{ Total } & An. gambiaes. I. & $350(20.37)$ & $1368(79.63)$ & 1718 & \\
\hline & An. funestus s. I. & $2(6.67)$ & $28(93.33)$ & 30 & \\
\hline & An. rufipes & 0 & $162(100)$ & 162 & \\
\hline
\end{tabular}

\section{Seasonal Densities Of Mosquitoes From Different Sites}

In the dry season, high numbers of Anopheline mosquitoes [1,214 (63.56\%)] were sampled in the dry season than in the rainy season [696 (36.44\%); $(z=$ -1.503, $p=0.1329)$; Table 2]. In the Sahel savannah zone (Kpalsogou, Pagaza and Libga), a total of 1,054 (67.91\%), 10 (9.62\%), 32 (45.5\%) vs. 498 (32.1), 48 (54.5\%) and 94 (90.38\%) female Anopheles mosquitoes were caught in the dry and rainy seasons. Whilst Konongo (the forest zone) high numbers of Anopheles were caught in the dry season [88.14\%, (104/118)] compared to the rainy season [11.86\%, (14/118)], in Anyakpor (the coastal savannah zone) there were more Anopheles collected in the rainy season [75\%, (42/56)] than in the dry season $[25 \%,(14 / 56)]$.

In all, the abundance of Anopheles gambiaes. I. was 62.28\% [1,070/1,718 (95\% Cl: $59.94-64.57)]$ in the dry season and 37.72\% [648/1718 (95\% Cl: $35.43-40.06)$ ] in the rainy season (Table 2). An. rufipes were also more abundant in the dry season [88.89\%, 144/162 (95\% Cl: 79.48 - 94.48)] than in the rainy season and $[11.11 \%, 18 / 162(95 \% \mathrm{Cl}: 6.70-17.24)]$. An. funestus was only caught during the rainy season at Kpalsogou, Libga and Anyakpor sites. No An. funestus was caught in the dry season at any of the study sites. 
Table 2

Total Mosquitoes collected from different sites in the three ecological zones in Ghana during the dry and rainy seasons.

\begin{tabular}{|c|c|c|c|c|c|}
\hline Season & Location & An. gambiae s.l. & An. funestus s.l. & An. rufipes & Total \\
\hline \multirow[t]{6}{*}{ Dry } & Kpalsogou & 910 & 0 & 144 & 1054 \\
\hline & Pagaza & 10 & 0 & 0 & 10 \\
\hline & Libga & 32 & 0 & 0 & 32 \\
\hline & Anyakpor & 14 & 0 & 0 & 14 \\
\hline & Konongo & 104 & 0 & 0 & 104 \\
\hline & Subtotal (\%) & $1,070(62.28)$ & 0 & 144 (88.89) & 1,214 \\
\hline \multicolumn{6}{|l|}{ Rainy } \\
\hline & Kpalsogou & 462 & 22 & 14 & 498 \\
\hline & Pagaza & 94 & 0 & 0 & 94 \\
\hline & Libga & 44 & 4 & 0 & 48 \\
\hline & Anyakpor & 38 & 0 & 4 & 42 \\
\hline & Konongo & 10 & 4 & 0 & 14 \\
\hline & Subtotal & 648 (37.72) & $30(100)$ & $18(11.11)$ & 696 \\
\hline Total & & $1,718(100)$ & $30(100)$ & $162(100)$ & 1,910 \\
\hline
\end{tabular}

Anopheles gambiae sibling species composition

A sub-sample of 538 An. gambiaes. I. from all study sites were analysed for the identification of their respective sibling species. Overall, An. coluzzii accounted for 63\% (95\% Cl: 57.10 - 68.91), followed by An. gambiae s. s. hereafter (An. gambiae) [27\% (95\% Cl: 21.66 - 32.55)], An. arabiensis [9\% (95\% Cl: 6.22 - 13.57)] and An. melas [1\% (95\% Cl: $0.13-3.00)]$.

In Kpalsogou, 12\% (194/1362) of An. gambiaes. I. were analyzed and of these 72\% [140/194 (95\% Cl: 61.99 - 50.56)] were An. coluzzii, 17\% [32/194 (95\% Cl: 10.01 - 25.71)] were An. gambiae and 11\% [22/194 (95\% Cl: 6.07 - 19.79)] were An. arabiensis. In Pagaza, out of the 104 An. gambiae s. I. analyzed, 67\% [70/104 (95\% Cl: 52.78 - 79.28)] were An. coluzzii, 25\% [26/104 (95\% Cl: 14.48 - 39.23)] were An. gambiae s. s. and 8\% [8/104 (95\% Cl: 2.49 - 19.40)] were An. arabiensis. Out of the 74 An. gambiaes. I. analyzed in Libga, 54\% [40/74 (95\% Cl: 37.13 - 70.15)] were An. gambiae, 27\% [20/74 (95\% Cl: 14.37 - 44.39)] were An. arabiensis and 19\% [14/74 (95\% Cl: 8.56 - 35.71)] were An. coluzzii.

In Anyakpor (the coastal zone), out of the 52 An. gambiaes. I. analyzed for sibling species, 84\% [44/52 (95\% Cl:64.27 - 94.95)] were An. coluzzii, and the rest were An. gambiae [8\% (2/26);95\% Cl: 1.34 - 26.60] and An. melas [8\% (2/26); 95\% Cl: 0.12 - 2.95]. In contrast, the forest zone (Konongo) had only An. coluzzii [63\% (72/114); 95\% Cl:49.30 - 75.24] and An. gambiae [37\% (42/114); 95\% Cl: $24.76-50.70]$.

The seasonal composition of the two malaria vectors (An. coluzzii and An. gambiae) varied at the different sites; in the Sahel savannah zone; An. coluzzii was higher outdoors ( $41.2 \%$ vs. $4.4 \%$ ) than indoors (26.5\% vs. $1.5 \%)$ for Kpalsogou and Pagaza in the dry season (Figure $2 \mathrm{~A})$. In contrast, Libga had more An. gambiae dominating outdoors (7.4\%) than indoors (4.4\%). In Konongo, high densities of An. coluzzii and An. gambiae was detected indoors (39.7\% vs. $22.1 \%$ ) compared to outdoors (5.8\% vs. $2.9 \%)$.

In the rainy season, An. arabiensis, An. coluzzii and An. gambiae were caught both indoors and outdoors in Kpalsogou, Pagaza, and Libga (Figure 2B). High densities of An. coluzzii were caught indoors (25\%) than outdoors (6.7\%) in Anyakpor. However, in Konongo the densities of An. culuzzii and An. gambiae were slightly higher indoors (5.1\% vs. $3.1 \%)$ than outdoors $(2.7 \%$ vs. $2.7 \%)$.

Kdr resistance mutations between indoor resting and outdoor resting Anopheles gambiae

A total of 538 Anopheles gambiae s.I samples were genotyped for the presence of L1014S, L1014F and G119S Ace-1 mutations. The L1014F kdrallele was identified in $100 \%$ (538) of the samples, with the majority of mosquitoes being homozygous for the $k d r$ allele (70.6\%; 380/538). Overall, the $k d r$ mutation frequency at Sahel savannah sites (Kpalsogou, Pagaza and Libga) was higher in mosquitoes resting indoors (0.90) than outdoors (0.84). In the forest zone (Konongo), a higher kdrfrequency was detected in mosquitoes resting outdoors (0.9) than indoors (0.79). In the coastal zone (Anyakpor), a similar $k d r$ frequency was detected in mosquitoes collected indoors (0.88) and outdoors (0.83). No KdrL1014S mutation was identified in this study.

An. arabiensis collected from outdoors at Pagaza and Libga had higher kdrmutations (0.75 vs. 0.86) compared to indoors (0 vs. 0.83$)$. However, in Kpalsogou An. arabiensis had higher kdrmutations indoor (1) than outdoor (0.88) (Table 3). Indoor resting An. coluzzii from Kpalsogou (0.90), and Pagaza (0.90) had a higher kdrmutation frequency than outdoor resting An. coluzzii (0.84 vs. 0.70). An. gambiae caught outdoor had a higher Kdr mutation frequency in Pagaza (0.88) and Libga (0.86) than indoor resting An. gambiae (0.5 vs. 0.83). 
The G119S Ace-1 mutations was detected in 79.9\% (215/538) of the mosquitoes tested (Table 4). All the mosquitoes with the resistant allele were heterozygous for this mutation. Overall, similar Ace-1 mutations frequencies was detected in indoor and outdoor resting mosquitoes in Sahel savannah zone (0.76 vs. 0.78). In the forest zone, Ace 1 mutations was slightly higher in mosquitoes resting indoors (0.87) than outdoors (0.80), but higher in mosquitoes resting outdoor (1) than indoor (0.76) in the coastal zone.

The frequency of Ace-1 mutation was similar for An. coluzzii collected indoors and outdoors in Kpalsogou (0.38 vs. 0.39$)$ and Libga (0.5 vs. 0.5). However, high Ace-1 mutation was detected in outdoor (0.42) than indoor (0.35) resting An. coluzzii in Pagaza (Table 4). In Kpalsogou, Pagaza, and Libga (Sahel savannah sites), the Ace-1 mutation was higher for $A n$. gambiae. resting indoors $(0.5,0.5,0.38)$ than outdoors $(0.38,0.42,0.36)$

Table 3

Frequency of $K d r$ L1014F mutation in the different species of Anopheles gambiae complex.

\begin{tabular}{|c|c|c|c|c|c|c|c|c|c|c|c|c|c|c|c|c|c|}
\hline \multirow[t]{3}{*}{ Site } & \multirow[t]{3}{*}{ Location } & \multicolumn{4}{|c|}{ An. arabiensis } & \multicolumn{4}{|c|}{ An. coluzzii } & \multicolumn{4}{|c|}{ An. gambiaes. s. } & \multicolumn{4}{|c|}{ An. melas } \\
\hline & & \multirow[b]{2}{*}{$\begin{array}{l}\text { No. } \\
\text { tested }\end{array}$} & \multicolumn{3}{|c|}{$\begin{array}{l}\text { Kdr } \\
\text { L1014 }\end{array}$} & \multirow[b]{2}{*}{$\begin{array}{l}\text { No. } \\
\text { tested }\end{array}$} & \multicolumn{3}{|c|}{$\begin{array}{l}\text { Kdr } \\
\text { L1014 }\end{array}$} & \multirow[b]{2}{*}{$\begin{array}{l}\text { No. } \\
\text { tested }\end{array}$} & \multicolumn{3}{|c|}{$\begin{array}{l}\text { Kdr } \\
\text { L1014 }\end{array}$} & \multirow[b]{2}{*}{$\begin{array}{l}\text { No. } \\
\text { tested }\end{array}$} & \multicolumn{2}{|c|}{$\begin{array}{l}K d r \\
\text { L1014 }\end{array}$} & \multirow[b]{2}{*}{$\mathrm{F}(K d r)$} \\
\hline & & & RS & $\mathrm{RR}$ & $\mathrm{F}(K d r)$ & & RS & $\mathrm{RR}$ & $\mathrm{F}(K d r)$ & & RS & $\mathrm{RR}$ & $\mathrm{F}(K d r)$ & & RS & $\mathrm{RR}$ & \\
\hline \multirow[t]{3}{*}{ Kpalsogou } & Indoor & 6 & 0 & 6 & 1 & 58 & 12 & 46 & 0.90 & 8 & 0 & 8 & 1 & & & & \\
\hline & Outdoor & 16 & 4 & 12 & 0.88 & 82 & 26 & 56 & 0.84 & 24 & 4 & 20 & 0.92 & & & & \\
\hline & Total & 22 & & & & 140 & & & & 32 & & & & & & & \\
\hline \multicolumn{18}{|l|}{ Pagaza } \\
\hline & Indoor & 0 & 0 & 0 & 0 & 20 & 4 & 16 & 0.9 & 2 & 2 & 0 & 0.5 & & & & \\
\hline & Outdoor & 8 & 4 & 4 & 0.75 & 50 & 30 & 20 & 0.7 & 24 & 6 & 18 & 0.88 & & & & \\
\hline & Total & 8 & & & & 70 & & & & 26 & & & & & & & \\
\hline \multicolumn{18}{|l|}{ Libga } \\
\hline & Indoor & 6 & 2 & 4 & 0.83 & 6 & 0 & 6 & 1 & 18 & 6 & 12 & 0.83 & & & & \\
\hline & Outdoor & 14 & 4 & 10 & 0.86 & 8 & 0 & 8 & 1 & 22 & 2 & 20 & 0.95 & & & & \\
\hline & Total & 20 & & & & 14 & & & & 40 & & & & & & & \\
\hline \multicolumn{18}{|l|}{ Anyakpor } \\
\hline & Indoor & & & & & 32 & 4 & 28 & 0.94 & 0 & 0 & 0 & 0 & 2 & 2 & 0 & 0.5 \\
\hline & Outdoor & & & & & 12 & 0 & 12 & 1 & 4 & 2 & 2 & 0.75 & 2 & 0 & 2 & 1 \\
\hline & Total & & & & & 44 & & & & 4 & & & & 4 & & & \\
\hline \multicolumn{18}{|l|}{ Konongo } \\
\hline & Indoor & & & & & 60 & 24 & 36 & 0.80 & 34 & 16 & 18 & 0.76 & & & & \\
\hline & Outdoor & & & & & 12 & 0 & 12 & 1.00 & 8 & 4 & 4 & 0.75 & & & & \\
\hline & Total & & & & & 72 & & & & 42 & & & & & & & \\
\hline
\end{tabular}

Abbreviations: RR homozygote resistant, RS heterozygote resistant, F frequency 
Table 4

Frequencies of Ace-1 mutation of An. gambiaes. I. at the different sites in the three ecological zones in Ghana.

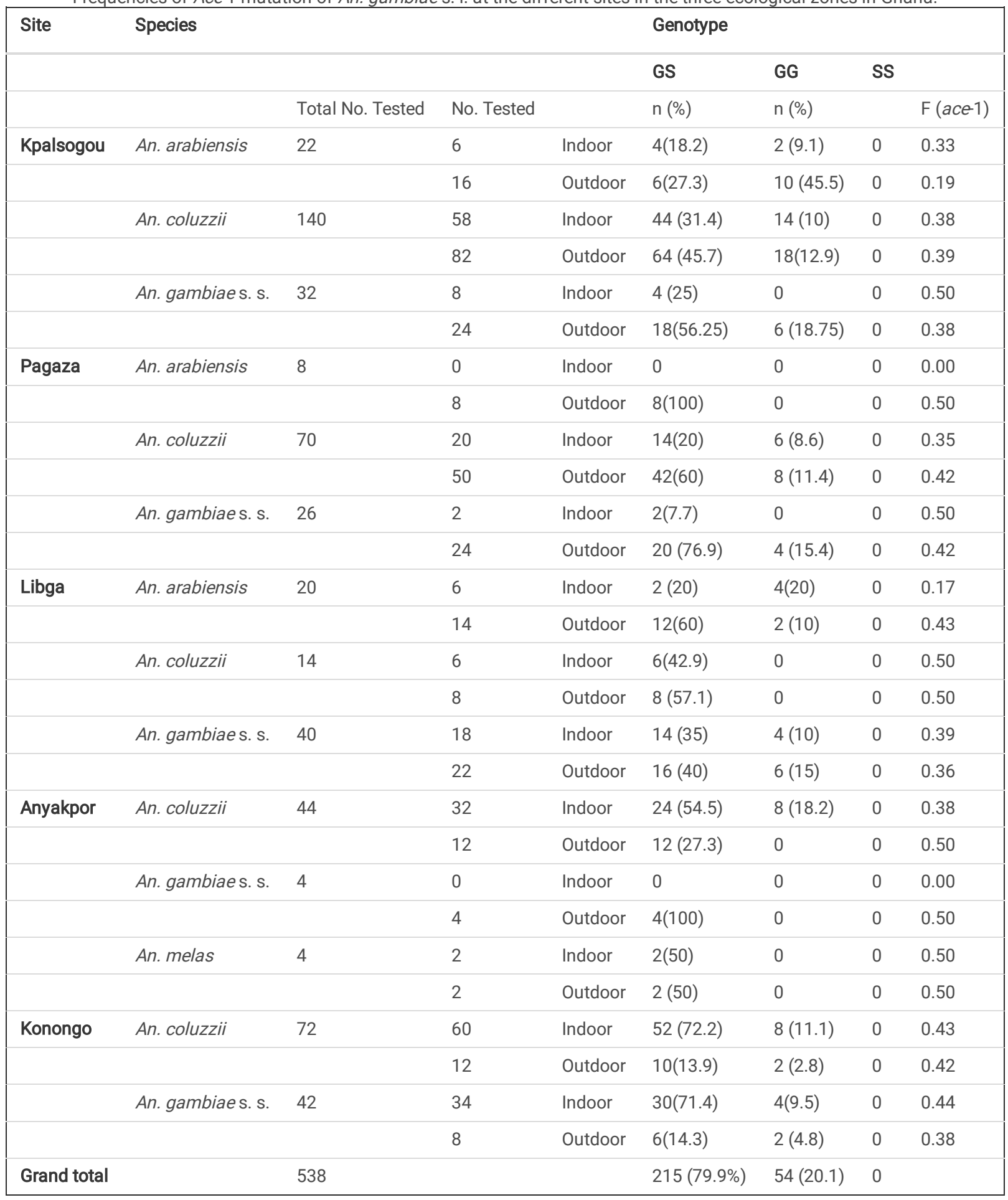

Abbreviations: GS heterozygote resistant, GG homozygote susceptible, SS homozygote resistant

\section{Blood meal sources}

The 362 An. gambiaes. I. blood fed mosquito specimen analyzed for blood meal origins revealed a total human blood index (HBI) of 70.2\% (254/362) across all sites. Overall, indoor resting mosquitoes had a slightly higher [73.1\%, (136/186)] HBI than outdoor [67\%, (118/176)] resting ones. In the savannah zone (Kpalsogou, Libga and Pagaza), the overall HBI of mosquitoes resting outdoors was higher [67.5\%, (52/77)] than indoor resting mosquitoes [32.5\% (25/77)]. In Kpalsogou, the human blood index (HBI) for An. arabiensis, An. coluzzii and An. gambiae caught resting indoor and outdoor was $100 \%, 68.4 \%$ and $50 \%$ vs. $40 \%, 70 \%$ and $54.5 \%$ respectively (Table 5 ). Only indoor and outdoor resting An. coluzzii were positive for human blood with an $\mathrm{HBI}$ of $66.7 \%$ and $100 \%$ respectively in the coastal zone (Anyakpor) (Table 5). In Konongo (Forest zone) the overall HBI was similar for indoor (84.7\%) and outdoor (85.7\%) resting mosquitoes. The HBI for An. coluzzii, and An. gambiae caught resting indoor and outdoor was $92.3 \%$ and $75 \%$ vs. $88.2 \%$ and $100 \%$ at the Konongo site. 
Table 5: Blood meal origins of Anopheles mosquitoes collected from indoor and outdoor in three ecological zones in Ghana.

\begin{tabular}{|c|c|c|c|c|c|c|c|}
\hline \multirow[t]{2}{*}{ Site } & \multirow[t]{2}{*}{ Blood-meal origins } & \multicolumn{2}{|c|}{ An. arabiensis } & \multicolumn{2}{|c|}{ An. coluzzii } & \multicolumn{2}{|c|}{ An. gambiaes. s. } \\
\hline & & Indoor & Outdoor & Indoor & Outdoor & Indoor & Outdoor \\
\hline \multirow[t]{7}{*}{ Kpalsogou } & Number tested & 2 & 10 & 38 & 60 & 4 & 22 \\
\hline & Human & $2(100)$ & $4(40)$ & $26(68.4)$ & $42(70)$ & $2(50)$ & $12(54.5)$ \\
\hline & Goat & 0 & $6(60)$ & $10(26.5)$ & $10(16.7)$ & $2(50)$ & $10(45.5)$ \\
\hline & Cow & 0 & 0 & $2(5.3)$ & $4(6.7)$ & 0 & 0 \\
\hline & Dog & 0 & 0 & 0 & $4(6.7)$ & 0 & 0 \\
\hline & $\mathrm{HBI}$ & 100 & 40 & 68.4 & 70 & 50 & 54.5 \\
\hline & $\mathrm{BBI}$ & 0 & 0 & 5.3 & 6.7 & 0 & 0 \\
\hline \multirow[t]{5}{*}{ Pagaza } & Number tested & 0 & 6 & 16 & 8 & 2 & 8 \\
\hline & Human & 0 & $4(66.7)$ & $8(50)$ & $14(77.8)$ & $2(100)$ & $6(75)$ \\
\hline & Goat & 0 & 2 (33.3) & $8(50)$ & $4(22.2)$ & 0 & $2(25)$ \\
\hline & $\mathrm{HBI}$ & 0 & 66.7 & 50 & 77.8 & 100 & 75 \\
\hline & $\mathrm{BBI}$ & 0 & 0 & 0 & 0 & 0 & 0 \\
\hline \multirow[t]{8}{*}{ Libga } & Number tested & 6 & 10 & 2 & 8 & 12 & 16 \\
\hline & Human & $4(66.7)$ & $8(80)$ & $2(100)$ & $8(100)$ & 4 (33.3) & $6(37.5)$ \\
\hline & Goat & 2 (33.3) & $2(20)$ & 0 & 0 & $8(66.7)$ & $8(50.0)$ \\
\hline & Dog & 0 & 0 & 0 & 0 & 0 & $2(12.5)$ \\
\hline & $\mathrm{HBI}$ & 66.7 & 80 & 100 & 100 & 33.3 & 37.5 \\
\hline & $\mathrm{BBI}$ & 0 & 0 & 0 & 0 & 0 & 00 \\
\hline & Number tested & & & 12 & 1 & 0 & 2 \\
\hline & Human & & & $8(66.7)$ & $2(100)$ & 0 & 0 \\
\hline \multirow[t]{3}{*}{ Anyakpor } & Dog & & & $4(33.3)$ & 0 & 0 & $2(100)$ \\
\hline & HBI & & & 66.7 & 100 & 0 & 0 \\
\hline & $\mathrm{BBI}$ & & & 0 & 0 & 0 & 0 \\
\hline \multirow[t]{7}{*}{ Konongo } & Number tested & & & 52 & 8 & 34 & 6 \\
\hline & Human & & & 48 (92.3) & $6(75)$ & $30(88.2)$ & $6(100)$ \\
\hline & Goat & & & $4(7.7)$ & 0 & $4(11.8)$ & 0 \\
\hline & Pig & & & 0 & $2(25)$ & 0 & 0 \\
\hline & Un-identified & & & 3 & 0 & 0 & 0 \\
\hline & $\mathrm{HBI}$ & & & 92.3 & 75 & 88.2 & 100 \\
\hline & $\mathrm{BBI}$ & & & 0 & 0 & 0 & 0 \\
\hline
\end{tabular}

Abbreviations: $\mathrm{HBI}$, Human blood index; BBI, bovine blood index

\section{Sporozoites infection rates}

A total of 68 pools of head and thoraces of Anopheline mosquitoes (20 Kpalsogou, 8 Pagaza, and 16 Libga, 8 Anyakpor, 16 Konongo) were constituted and tested for Plasmodium falciparum Circumsporozoite protein (CSP). Four pools (2 pools from Kpalsogou and 2 pools from Konongo) tested positive for Plasmodium falciparum Circumsporozoite protein giving an overall infection rate of $0.6 \%$. Overall, the sporozoite rate was higher for indoor resting mosquitoes from Kpalsogou (5.0\%) and Konongo (2.5\%) (Table 6). None of the mosquitoes collected outdoors in Kpalsogou, Pagaza, Libga, Anyakpor 
and Konongo was positive for $P$. falciparum CSP. CSP was detected in only An. coluzzii (2.5\%) collected in the rainy season in Kpalsogou and in the dry season (2.0\%) in Konongo.

Table 6: Sporozoite infections in Anopheles gambiaes. I from three ecological zones in Ghana.

\begin{tabular}{|c|c|c|c|c|c|c|c|}
\hline & \multirow[t]{2}{*}{ Location } & \multicolumn{2}{|c|}{ An. arabiensis } & \multicolumn{2}{|l|}{ An. coluzzii } & \multicolumn{2}{|c|}{ An. gambiaes. s. } \\
\hline & & Pools tested & Pf +ve & Pools. tested & $\mathrm{Pf}+\mathrm{ve}$ & Pools & Pf +ve \\
\hline \multirow[t]{2}{*}{ Kpalsogou } & Indoor & - & - & 4 & $2(5 \%)$ & - & - \\
\hline & Outdoor & 2 & 0 & 8 & 0 & 6 & 0 \\
\hline \multirow[t]{2}{*}{ Pagaza } & Indoor & - & - & - & - & 4 & 0 \\
\hline & Outdoor & 2 & 0 & 2 & 0 & - & - \\
\hline \multirow[t]{2}{*}{ Libga } & Indoor & & & 4 & 0 & & \\
\hline & Outdoor & & & 12 & 0 & & \\
\hline \multirow[t]{2}{*}{ Anyakpor } & Indoor & & & 4 & 0 & - & - \\
\hline & Outdoor & & & 0 & 0 & 2 & 0 \\
\hline \multirow[t]{2}{*}{ Konongo } & Indoor & & & 8 & $2(2.5 \%)$ & 6 & 0 \\
\hline & Outdoor & & & 2 & 0 & 2 & 0 \\
\hline
\end{tabular}

\section{Discussion}

Behavioral diversification in vector population threatens to counteract vector control strategies in areas with widespread use of LLINs and IRS (6, 7, 13-15, 49). This study investigated the behavioral response of malaria vectors for resting, feeding choices and infection rates in the context of increasing insecticide resistance in malaria vectors. Overall, this study revealed high outdoor resting densities of malaria vectors but with lower infection rates. There were high numbers of mosquitoes with insecticide resistance mutations resting indoors compared to outdoors at the different sites in the three ecological zones in Ghana.

Anopheles coluzzii and An. gambiae from Kpalsogou, Libga and Pagaza (Sahel savannah zone) showed increased outdoor resting tendency in both the rainy and dry season despite high coverage and usage of LLINS and IRS) (50). This could drive malaria transmission higher outdoors since these main malaria vectors can bite unprotected humans outdoors and also rest outdoors to avoid contact with the insecticides being used indoors (51, 52). This behavioral change in malaria vector population is detrimental to vector control $[13,14]$, which mainly target vectors resting indoors. Such variation in the relative frequency and behavior of this two main malaria vectors has been reported in studies from Equatorial Guinea (13), Tanzania (14, 19), but, in contrast to studies from Kenya $(20,49)$ which reported high indoor resting densities of An. gambiae and An. coluzzii.

In this study, it was found that the frequency of kdrwest mutation L1014F and the Ace-1 mutation were of higher frequency in indoor resting An. coluzzii and An. gambiae in the sahel-savannah sites compared to the forest and coastal savannah sites. This may be because the interventions indoors are not able to kill the mosquitoes with higher $k d r$ mutations and mosquitoes with less mutations have resorted to feed and rest outdoors to avoid contact with insecticides that are indoors $(31,67-69)$. This study is in conformity to previous studies in Ghana $(33,34)$ which reported similar occurrence of $K d r$ L1014F frequencies in An. coluzzii. This study is also in conformity to previous studies in Ghana $(33,34)$ which reported no Kdr-east allele. However, in contrast to this study, Kdr-east allele (1014S) have been reported in Burkina Faso in An. coluzzii, An. gambiae, and An. arabiensis (53), and in both An. coluzzii and An. gambiae in Togo (25).

The blood meal analyses revealed a large proportion of the malaria vectors preferred feeding on humans than animals in almost all sites. This humanhost choice and higher outdoor resting proportions of An. gambiae and An. coluzzii poses a great concern in malaria elimination efforts due their efficiency in transmitting malaria. This study findings is in agreement with studies by Orsborne et al. (54) in the coastal area of Ghana, which reported that blood-fed mosquitoes caught indoors had higher $\mathrm{HBI}$ and lower $\mathrm{BBI}$ than those caught outdoors.

Sporozoite infection was only found in indoor resting malaria vectors collected during the wet season from Kpalsogou and dry season from Konongo. This might mean that malaria transmission is higher indoors than outdoors despite the deployment of LLINs in all sites and IRS in Kpalsogou (55). In 
contrast, studies from Kenya, Burkina Faso have shown higher sporozoite infection in An. gambiae and An. coluzzii resting outdoors (20, 49, 56), and in An. gambiae sampled from Northern Ghana (7).

\section{Conclusions}

The study revealed high densities of $A n$. coluzzii and $A n$. gambiae resting outdoors with low genotypic resistance compared to indoor resting mosquitoes that may be triggered by current insecticide-based indoor intervention. Such behavioral change can promote outdoor transmission since current vector strategies mainly target indoor resting malaria vectors. There is a need for further screening of other resistance mutations in this population for better resistance management strategies. Therefore, continuous monitoring of vector behavior in surveillance programmes is recommended and complementary malaria control interventions are needed to control outdoor resting mosquitoes.

\section{List Of Abbreviations}

BBI, bovine blood index; CSP, circumsporozoite protein; GS, heterozygote resistant; GG, homozygote susceptible; HBI, human blood index; IRS, indoor residual spray; KDR, Knockdown resistant gene; LLINs, long-lasting insecticidal nets; PCR, polymerase chain reaction; PSC, pyrethrum spray catch; SS, homozygote resistant.

\section{Declarations}

\section{Ethics approval}

Not applicable

\section{Consent for publication}

Not applicable

\section{Availability of data and materials}

The datasets used and/or analysed during the current study are available from the corresponding author on reasonable request.

\section{Competing interests}

The authors declare that they have no competing interests.

\section{Funding}

This study was supported by a grant from the National Institute of Health (NIH: R01 A1123074 and D43 TW 011513). The funders had no role or influence on the design of this study, the collection, analysis, and interpretation of the data collected as well as in writing this manuscript.

\section{Authors' contributions}

AOF designed, performed the field and laboratory work, analyzed data and drafted the manuscript. YAA conceived and supervised the study, analyzed data and revised the manuscript. SKA and IAH supervised the study and revised the manuscript. IAH, SBD, ARM and IKS performed field and laboratory experiments.

\section{Acknowledgments}

The authors are grateful to the people of Anyakpor, Konongo, Kpalsogou, Libga, and Pagaza for permitting us to sample mosquitoes in their communities and farms. The authors also thank all the community field assistants for helping in the data collection in the various communities.

\section{References}

1. World Health Organisation. World Malaria Report Source: file:///C:/Users/dell/Downloads/9789240015791-double-page-viewpdf. 2020.

2. USAID President's Malaria Initiative FY. Ghana Malaria Operational Plan. Source: https://wwwpmigov/docs/default-source/default-documentlibrary/malaria-operational-plans/fy20/fy-2020-ghana-malaria-operational-planpdf?sfvrsn=6. 2020.

3. Dhiman S. Are malaria elimination efforts on right track? An analysis of gains achieved and challenges ahead. Infectious Diseases of Poverty. 2019;8(1):14.

4. World Health Organisation. WHO guidance for countries on combining indoor residual spraying and long-lasting insecticidal nets. Source: https://appswhoint/iris/bitstream/handle/10665/338635/WHO-HTM-GMP-MPAC-20142-engpdf. 2014. 
5. Mutuku FM, King CH, Mungai P, Mbogo C, Mwangangi Js, Muchiri EM, et al. Impact of insecticide-treated bed nets on malaria transmission indices on the south coast of Kenya. Malar J. 2011;10:356.

6. Bayoh MN, Mathias DK, Odiere MR, Mutuku FM, Kamau L, Gimnig JE, et al. Anopheles gambiae: historical population decline associated with regional distribution of insecticide-treated bed nets in western Nyanza Province, Kenya. Malar J. 2010;9:62.

7. Coleman S, Dadzie SK, Seyoum A. A reduction in malaria transmission intensity in Northern Ghana after 7 years of indoor residual spraying. Malar $\mathrm{J}$ 2017;16(324).

8. Mawejje HD, Kilama M, Kigozi SP, Musiime AK, Kamya M, Lines J, et al. Impact of seasonality and malaria control interventions on Anopheles density and species composition from three areas of Uganda with differing malaria endemicity. Malar J. 2021;20(1):138.

9. Smithuis FM, Kyaw MK, Phe UO, van der Broek I, Katterman N, Rogers C, et al. The effect of insecticide-treated bed nets on the incidence and prevalence of malaria in children in an area of unstable seasonal transmission in western Myanmar. Malar J. 2013;12:363.

10. Bhatt S, Weiss DJ, Cameron E, Bisanzio D, Mappin B, Dalrymple U, et al. The effect of malaria control on Plasmodium falciparum in Africa between 2000 and 2015. Nature. 2015;526(7572):207-11.

11. Zhou G, Afrane YA, Vardo-Zalik AM, Atieli H, Zhong D, Wamae P, et al. Changing patterns of malaria epidemiology between 2002 and 2010 in Western Kenya: the fall and rise of malaria. PLoS One. 2011;6(5):e20318.

12. Cohen JM, Smith DL, Cotter C, Ward A, Yamey G, Sabot OJ, et al. Malaria resurgence: a systematic review and assessment of its causes. Malaria Journal. 2012;11(1):122.

13. Reddy MR, Overgaard HJ, Abaga S. Outdoor host seeking behaviour of Anopheles gambiae mosquitoes following initiation of malaria vector control on Bioko Island, Equatorial Guinea. Malar J 2011;10(184).

14. Russell TL, Govella NJ, Azizi S, Drakeley CJ, Kachur SP, Killeen GF. Increased proportions of outdoor feeding among residual malaria vector populations following increased use of insecticide-treated nets in rural Tanzania.. Malar J 2011;10(80).

15. Derua YA, Alifrangis M, Hosea KM, Meyrowitsch DW, Magesa SM, PE M, et al. Change in composition of the Anopheles gambiae complex and its possible implications for the transmission of malaria and lymphatic filariasis in north-eastern Tanzania.. Malar J 2012;11(188).

16. Ototo EN, Mbugi JP, Wanjala CL, Zhou G, Githeko AK, Yan G. Surveillance of malaria vector population density and biting behaviour in western Kenya. Malaria Journal. 2015;14(1):244.

17. Moiroux N, Gomez MB, Pennetier C, Elanga E, Djènontin A, Chandre F, et al. Changes in Anopheles funestus Biting Behavior Following Universal Coverage of Long-Lasting Insecticidal Nets in Benin. J Infect Dis. 2012;206(10):1622-9.

18. Sougoufara S, Diédhiou SM, Doucouré S, Diagne N, Sembène PM, Harry M, et al. Biting by Anopheles funestus in broad daylight after use of longlasting insecticidal nets: a new challenge to malaria elimination. Malaria Journal. 2014;13(1):125.

19. Kreppel KS, Viana M, Main BJ, Johnson PCD, Govella NJ, Lee Y, et al. Emergence of behavioural avoidance strategies of malaria vectors in areas of high LLIN coverage in Tanzania. Scientific reports. 2020;10(1):14527.

20. Machani MG, Ochomo E, Amimo F, Kosgei J, Munga S, Zhou G, et al. Resting behaviour of malaria vectors in highland and lowland sites of western Kenya: Implication on malaria vector control measures. PloS one. 2020;15(2):e0224718-e.

21. Msugupakulya BJ, Kaindoa EW, Ngowo HS. Preferred resting surfaces of dominant malaria vectors inside different house types in rural south-eastern Tanzania. Malaria Journal. 2020;19(22).

22. Bayoh MN, Walker ED, Kosgei J, Ombok M, Olang GB. Persistently high estimates of late night, indoor exposure to malaria vectors despite high coverage of insecticide treated nets.. Parasites \& Vectors 2014;7(380).

23. Zoh DD, Ahoua Alou LP, Toure M, Pennetier C, Camara S, Traore DF, et al. The current insecticide resistance status of Anopheles gambiae (s.I.) (Culicidae) in rural and urban areas of Bouaké, Côte d'Ivoire. Parasites vectors. 2018;11(1):118-.

24. Amoudji AD, Ahadji-Dabla KM, Hien AS, Apétogbo YG, Yaméogo B, Soma DD, et al. Insecticide resistance profiles of Anopheles gambiae s.l. in Togo and genetic mechanisms involved, during 3-year survey: is there any need for resistance management? Malaria Journal. 2019;18(1):177.

25. Djègbè I, Akoton R, Tchigossou G, Ahadji-Dabla KM, Atoyebi SM, Adéoti R, et al. First report of the presence of L1014S Knockdown-resistance mutation in Anopheles gambiaes.s and Anopheles coluzzii from Togo, West Africa. Wellcome open research. 2018;3:30.

26. Djègbè I, Boussari O, Sidick A, Martin T, Ranson H, Chandre F, et al. Dynamics of insecticide resistance in malaria vectors in Benin: first evidence of the presence of L1014S kdr mutation in Anopheles gambiae from West Africa. Malaria Journal. 2011;10(1):261.

27. Ranson $\mathrm{H}$, Abdallah H, Badolo A, Guelbeogo WM, Kerah -HC, Yangalbé-Kalnoné E, et al. Insecticide resistance in Anopheles gambiae: data from the first year of a multi-country study highlight the extent of the problem. Malaria Journal. 2009;8(1):299.

28. Dabiré KR, Diabaté A, Namontougou M, Djogbenou L, Kengne P, Simard F, et al. Distribution of insensitive acetylcholinesterase (ace-1R) in Anopheles gambiae s.l. populations from Burkina Faso (West Africa). Tropical medicine \& international health: TM \& IH. 2009;14(4):396-403.

29. Nwane P, Etang J, Chouaibou M, Toto JC, Kerah-Hinzoumbe C, Mimpfoundi R, et al. Trends in DDT and pyrethroid resistance in Anopheles gambiae s.s. populations from urban and agro-industrial settings in southern Cameroon. BMC Infect Dis. 2009;9:163.

30. Nwane P, Etang J, Chouaïbou M, Toto JC, Mimpfoundi R, Simard F. Kdr-based insecticide resistance in Anopheles gambiae s.s populations in Cameroon: spread of the L1014F and L1014S mutations. BMC Research Notes. 2011;4(1):463.

31. Ochomo E, Bayoh MN, Brogdon WG, Gimnig JE, Ouma C, Vulule JM, et al. Pyrethroid resistance in Anopheles gambiae s.s. and Anopheles arabiensis in western Kenya: phenotypic, metabolic and target site characterizations of three populations. Med Vet Entomol. 2013;27(2):156-64. 
32. Wanjala CL, Mbugi JP, Ototo E, Gesuge M, Afrane YA, Atieli HE, et al. Pyrethroid and DDT Resistance and Organophosphate Susceptibility among Anopheles spp. Mosquitoes, Western Kenya. Emerg Infect Dis. 2015;21(12):2178-81.

33. Hunt RH, Fuseini G, Knowles S, Stiles-Ocran J, Verster R, Kaiser ML, et al. Insecticide resistance in malaria vector mosquitoes at four localities in Ghana, West Africa. Parasites vectors. 2011;4(1):107.

34. Baffour-Awuah S, Annan AA, Maiga-Ascofare O, Dieudonné SD, Adjei-Kusi P, Owusu-Dabo E, et al. Insecticide resistance in malaria vectors in Kumasi, Ghana. Parasites vectors. 2016;9(1):633-

35. Pwalia R, Joannides J, Iddrisu A, Addae C, Acquah-Baidoo D, Obuobi D, et al. High insecticide resistance intensity of Anopheles gambiae (s.I.) and low efficacy of pyrethroid LLINs in Accra, Ghana. Parasites vectors. 2019;12(1):299.

36. Smith TA, Pemberton-Ross P, Penny MA. Resurgence of malaria infection after mass treatment: a simulation study.. Malar J 2019;18(409).

37. Nkumama IN, O'Meara WP, Osier FHA. Changes in Malaria Epidemiology in Africa and New Challenges for Elimination. Trends in Parasitology. 2017;33(2):128-40.

38. Awine T, Malm K, Peprah NY, Silal SP. Spatio-temporal heterogeneity of malaria morbidity in Ghana: Analysis of routine health facility data. PLoS One. 2018;13(1):e0191707.

39. Githinji EK, Irungu LW, Ndegwa PN, Machani MG, Amito RO, Kemei BJ, et al. Impact of Insecticide Resistance on P. falciparum Vectors' Biting, Feeding, and Resting Behaviour in Selected Clusters in Teso North and South Subcounties in Busia County, Western Kenya. J Parasitol Res. 2020;2020:9423682.

40. Maia MF, Robinson A, John A, Mgando J, Simfukwe E, Moore SJ. Comparison of the CDC Backpack aspirator and the Prokopack aspirator for sampling indoor- and outdoor-resting mosquitoes in Southern Tanzania. Parasit Vectors. 2011;4:124.

41. Muirhead-Thomson RC. A pit shelter for sampling outdoor mosquito populations. Bull World Health Organ. 1958;19(6):1116-8.

42. Gillies MT, Coetzee M. A supplement to the Anophelinae of Africa South of the Sahara. Publ Sth Afr Inst Med Res. 1987;55:1-143.

43. Scott JA, Brogdon WG, Collins FH. Identification of single specimens of the Anopheles gambiae complex by the polymerase chain reaction. Am J Trop Med Hyg. 1993;49(4):520-9.

44. Fanello C, Santolamazza F, della Torre A. Simultaneous identification of species and molecular forms of the Anopheles gambiae complex by PCRRFLP. Med Vet Entomol. 2002;16(4):461-4.

45. Echeverry DF, Deason NA, Makuru V, Davidson J, Xiao H, Niedbalski J, et al. Fast and robust single PCR for Plasmodium sporozoite detection in mosquitoes using the cytochrome oxidase I gene. Malaria Journal. 2017;16(1):230.

46. Kent RJ, Norris DE. Identification of mammalian blood meals in mosquitoes by a multiplexed polymerase chain reaction targeting cytochrome B. Am J Trop Med Hyg. 2005;73(2):336-42.

47. Ahadji-Dabla KM, Amoudji AD, Nyamador SW, Apétogbo GY, Chabi J, Glitho IA, et al. High Levels of Knockdown Resistance in Anopheles coluzzii and Anopheles gambiae (Diptera: Culicidae), Major Malaria Vectors in Togo, West Africa: A 2011 Monitoring Report. J Med Entomol. 2019;56(4):115964.

48. Gu W-D. Estimating sporozoite rates by examining pooled samples of mosquitoes. Trans R Soc Trop Med Hyg. 1995;89(4):359-60.

49. Degefa T, Yewhalaw D, Zhou G, Lee M-c, Atieli HE, Githeko AK, et al. Indoor and outdoor malaria vector surveillance in western Kenya: implications for better understanding of residual transmission. Malaria Journal. 2017;16(1):443.

50. Abuaku B, Ahorlu C, Psychas P, Ricks P, Oppong S, Mensah S, et al. Impact of indoor residual spraying on malaria parasitaemia in the BunkpuruguYunyoo District in northern Ghana. Parasites vectors. 2018;11(1):555.

51. Carrasco D, Lefèvre T, Moiroux N, Pennetier C, Chandre F, Cohuet A. Behavioural adaptations of mosquito vectors to insecticide control. Curr Opin Insect Sci. 2019;34:48-54.

52. Gatton ML, Chitnis N, Churcher T, Donnelly MJ, Ghani AC, Godfray HC, et al. The importance of mosquito behavioural adaptations to malaria control in Africa. Evolution. 2013;67(4):1218-30.

53. Namountougou M, Diabaté A, Etang J, Bass C, Sawadogo SP, Gnankinié O, et al. First report of the L1014S kdr mutation in wild populations of Anopheles gambiae M and S molecular forms in Burkina Faso (West Africa). Acta Trop. 2013;125(2):123-7.

54. Orsborne J, Mohammed A, Jeffries CL, Kristan M, Afrane YA, Walker T, et al. Evidence of extrinsic factors dominating intrinsic blood host preferences of major African malaria vectors. Scientific reports. 2020;10(1):741.

55. Atieli HE, Zhou G, Afrane Y, Lee MC, Mwanzo I, Githeko AK, et al. Insecticide-treated net (ITN) ownership, usage, and malaria transmission in the highlands of western Kenya. Parasites vectors. 2011;4:113.

56. Pombi M, Calzetta M, Guelbeogo WM, Manica M, Perugini E, Pichler V, et al. Unexpectedly high Plasmodium sporozoite rate associated with low human blood index in Anopheles coluzzii from a LLIN-protected village in Burkina Faso. Sci Rep. 2018;8(1):12806.

\section{Figures}




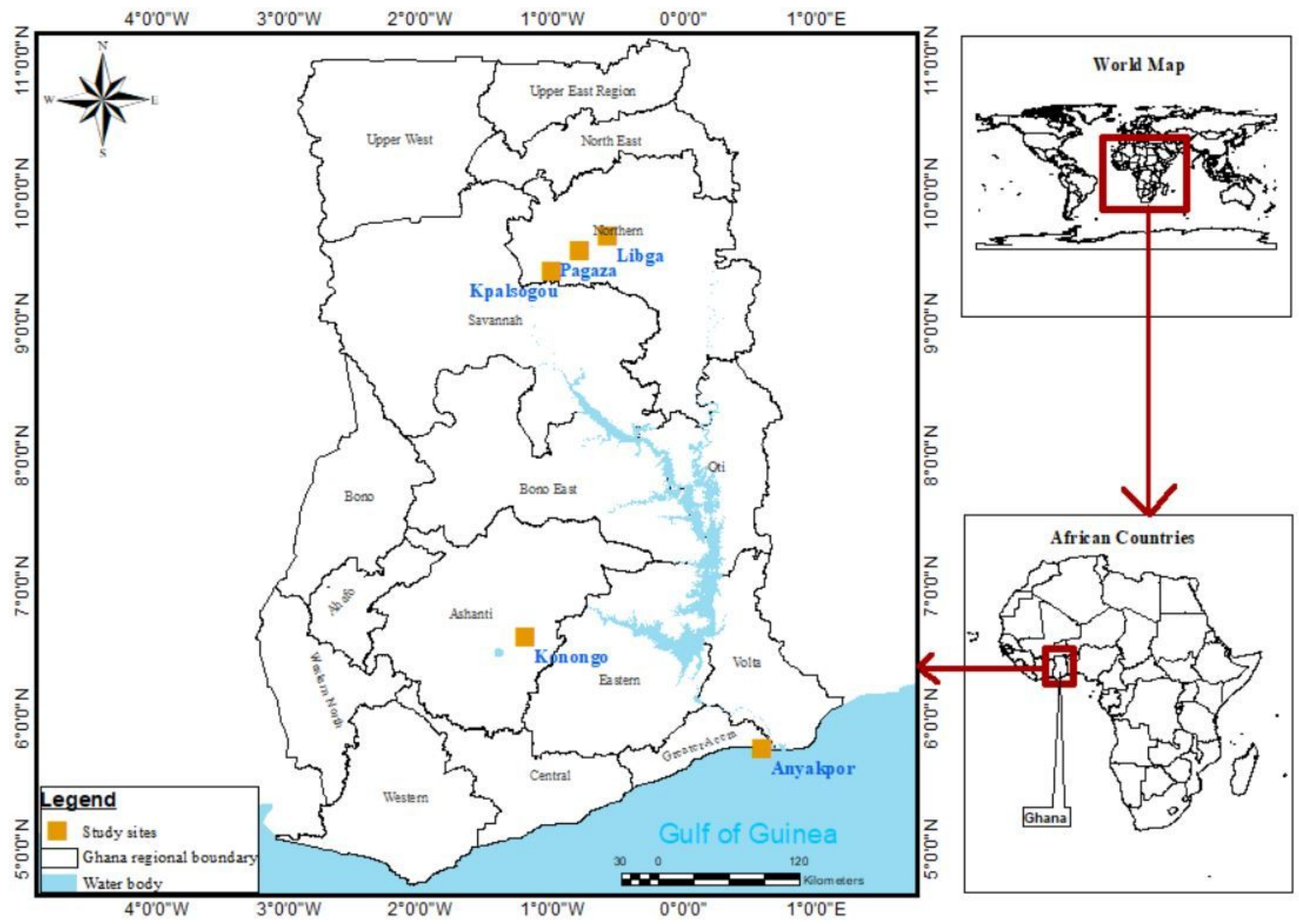

Figure 1

Map of Ghana showing the different study sites 


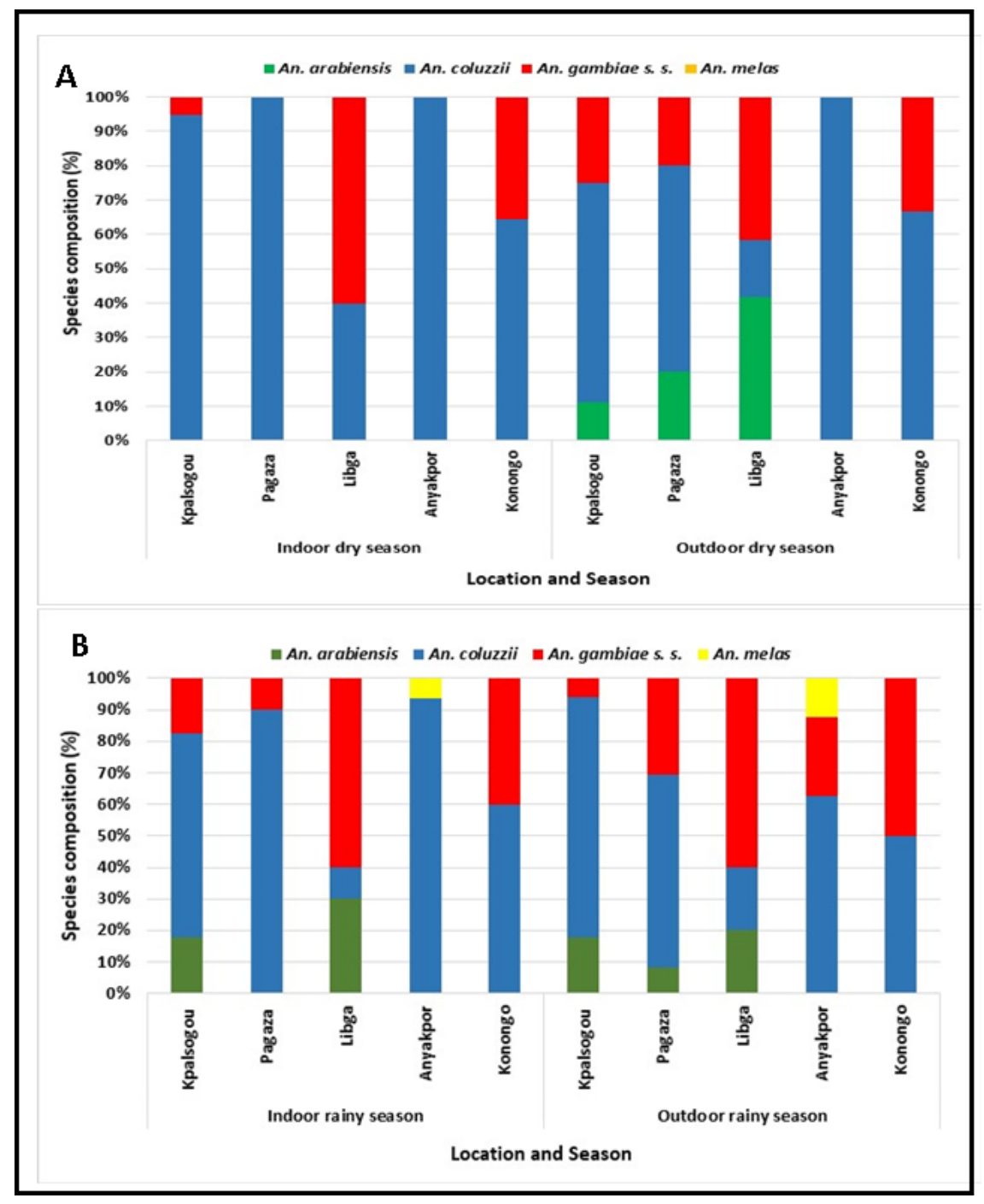

\section{Figure 2}

Seasonal composition of Anopheles species resting indoor and outdoor in A: Dry season and B: Rainy season in different sites at the three main ecological zones of Ghana.

\section{Supplementary Files}

This is a list of supplementary files associated with this preprint. Click to download.

- Graphicalabstract2.docx 